Lena Ninković

Faculty of Philology

University of Belgrade

Ph.D. student
371.3::811.134.2'243

https://doi.org/10.18485/zivjez.2020.40.1.1 Оригинални научни рад

\title{
SPATIAL, TEMPORAL AND EPISTEMIC PROXIMIZATION AS DYNAMIC EVENT CONSTRUAL STRATEGIES
}

The present paper examines the discursive construal of the Coronavirus as the proximizing entity in the Anglo-American political discourse with the goal of elucidating the pragmatic effects and underlying construal operations of threat representation. The research was carried out within the theoretical framework of cognitive pragmatics, and the data consists of the written samples and transcripts of the political statements made by the ruling party representatives at the Coronavirus public briefings. The corpora were concluded to be replete with linguistic forms that realize intersubjective positioning strategy for the sake of achieving shared cognitive viewpoint, thus legitimizing policies implemented during the pandemic.

Keywords: proximization, political discourse, legitimization, cognitive pragmatics, viewpoint.

\section{Introduction}

If we broadly define politics as the negotiation of opposing views, a struggle for power (Chilton \& Schäffner 2003; Wodak 2009), and reconciliation of social differences through discussion and persuasion (Cap 2008), then language would be its primary ideological tool for the construction of society, and Critical Discourse Studies (van Dijk 2009) instruments for political discourse deconstruction. Departing from the purely functional approaches

* lena.z.ninkovic@gmail.com 
within the $\mathrm{CDS}^{1}$, a new perspective on discourse analysis has emerged (Chilton 2004; Cap 2013; Hart 2014a; Hart \& Cap 2014) through the application of insights from Cognitive Linguistics, primarily focused on the notions of construal operations and dynamic online meaning construction. Cognitive Linguistic Approach to CDA "addresses the effects of ideological or perspectivized language use on hearers' mental representations and evaluations of reality" (Hart 2014a: 9). The dynamic process of conceptualization involves meaning creation by evoking background knowledge that provides conceptual content, and setting up mental representation of that knowledge through the construal process (Langacker 2007: 435; 1990: 61). Construal concerns the alternative ways in which a scene (situation, event, or relation) may be conceptualized relative to the manner in which language guides our "perception". The construal of any event involves utilization of construal operations (Croft \& Cruise 2004; Hart 2014a) grounded in our cognitive system which realize different discursive strategies. This paper aims at elucidating the pragmatic positioning strategies (spatial, temporal and epistemic proximization) that are based on our cognitive ability of simulated perspective taking. Such perspective is anchored in the pragmatic notion of deixis (Fillmore 1997 [1971]; Lyons 1977) corresponding to the conceptualizer's broadly defined spatial, temporal and epistemic ground as a reference point, and the cognitive linguistic notion of viewpoint (Langacker 1987), involving the vantage point from which an event is construed, and orientation and distance of other elements relative to this ground.

\section{Theoretical background}

\subsection{Construal Operations}

There is not a unified nomenclature of construal operations in the present Cognitive Linguistic literature; instead, they have been classified in more or less corresponding categories over the past two decades. As new construal operations are being discovered,

1 Primarily the application of Michael Halliday's Systemic Functional Grammar (SFG) (1985) in Critical Discourse Analysis (CDA). 
recurrent updates and variations of construal phenomena disallow the formation of an exclusive classification, thus showing a degree of arbitrariness (Croft \& Cruise 2004). However, all frameworks share the idea that several construal operations are utilized in the meaning construction of a single linguistic expression (Verhagen 2007). The first attempt, proposed by Ronald Langacker (1987: 116137) involved a tripartite classification of construal operations into Selection, Perspective and Abstraction, later updated into Specificity, Prominence, Perspective and Dynamicity (Langacker 2007: 435438). Specificity involves the construal of a scene in a fine-grained detail, as opposed to schematicity which imposes less information rich structure to certain facets of the scene in question. Prominence is related to profile/base and figure/ground alignment. A linguistic expression can single out its conceptual referent (profile) from the overall conceptual configuration (base). A figure/ground alignment purports to the salience of an entity (figure) in relation to the ground which is backgrounded. The most prominent category of construal operation - perspectivization, involves viewpoint, deixis and subjectivity/objectivity distinction (Langacker 2007: 436). An entity may be a subject or an object of conceptualization, or both. In ongoing discourse, the speaker and the addressee usually function as subjects of conceptualization, whilst the event they construe is an object, unless, for instance, they explicitly refer to themselves, in which case they would be both objects of conceptualization and conceptualizing subjects. The conceptualizer's viewpoint involves the vantage point and orientation. The vantage point from which we "see" the scene does not need to coincide with the speaker's location. We may as well adopt Sara's vantage point in saying Sara said to come to Belgrade, as the verb come can be highly deictically specified. Finally, dynamicity pertains to how a construed scene may dynamically unfold through processing time. Expressing the elements of conceptualization in different order may result in different meaning constructions. But this sequential processing ${ }^{2}$

2 We follow Langacker's distinction (2007) between sequential scanning - a construal operation that involves predication, and fictive motion, which does not have to be predicated. 
may also be evident in what Leonard Talmy calls fictive motion (Talmy 1996: 211-277) when dynamicity is applied to an object that is not inherently dynamic, as in the road winds through the field.

Construal operations in Talmy's classification (2000: 40-84) include Configurational Structure, Perspective, Distribution of Attention, and Force Dynamics. Image schematic representation of a scene is realized through the configurational structure as a basic construal operation. Distribution of Attention is a distinct subcategory of figure/ground alignment, while Force Dynamics pertains to the entity relations with respect to force (Talmy 1988 : 49-100), as in She blew me away, metaphorically structured through the image schematic pattern of force exertion.

In CLA approach to CDA, construal operations are revealed to realize ideologically fused discursive strategies that may, in a given context, contribute to the achievement of the desired social action. Based on Croft and Cruise's nomenclature (2004), Hart (2014a: 169) proposes the classification of discursive strategies based on the construal operations that realize them: Structural Configuration, Framing, Identification, and Positioning. Structural Configuration involves the schematic, skeletal, the least information rich mental representation of a scene, as well as participant roles and their relations. Further elaboration of such holistic representation is achieved through framing, that is based on defining a scene as belonging to a particular conceptual category, or employing metaphor to assign particular qualities to the content being construed. Identification is related to entities' salience, thus closely related to the aforementioned profile/base and figure/ground alignment. Positioning strategy involves the construal of a discourse space (cf. Chilton 2004), situatedness of the conceptualizer and positioning of other entities relative to the conceptualizer. In semantic positioning, the reference point functions as a viewpoint and contributes to the conventional meaning of a given linguistic expression. Pragmatic positioning involves the notion of deixis, when the conceptualizer's viewpoint corresponds to her/his spatial, temporal and epistemic situatedness in broader context, making them the deictic centre. 
SPATIAL, TEMPORAL AND EPISTEMIC PROXIMIZATION...

\begin{tabular}{|c|c|c|c|c|c|}
\hline & System & Gestalt & Comparison & Attention & Perspective \\
\hline $\begin{array}{l}\text { Structural } \\
\text { Configuration }\end{array}$ & & Schematisation & & & \\
\hline & & & Categorisation & & \\
\hline Framing & & & Metaphor & & \\
\hline & & & & Figure/Ground & \\
\hline Identification & $\simeq$ & & & Granularity & \\
\hline & 苋 & & & Viewing Frame & \\
\hline & $\frac{0}{\frac{\pi}{3}}$ & & & & Point of View \\
\hline Positioning & 气ू & & & & Deixis \\
\hline
\end{tabular}

Figure 1. Construal operations in the CLA (adapted from Hart 2014a:170)

\subsection{Proximization}

The strategy of proximization involves both the cognitive and pragmatic dimension since linguistic expression triggers the perlocutionary effect (legitimization) only through the forced construal it evokes. For the purpose of legitimization, the speaker resorts to proximization strategy of representing a distant antagonistic entity as intruding upon the deictic centre, thus exerting negative impact on the speaker and the addressee(s) (Cap 2013). The closeness of the threat may be construed relative to spatial axis, and metaphorically construed temporal or evaluative axes within the discourse space (Hart 2014b). Discourse space is a three dimensional abstraction from the material spatial domain and involves a mental representation of discourse content. The peripheral entity is referred to as ODC ('outside-deictic-centre'), while speaker and addressee(s) are IDC ('inside-deictic-centre'). The construal of all entities, their roles and relations is supported by mental spaces - the conceptual units that provide structure to concepts needed to be understood in ongoing discourse. Spatial 
proximization designates the antagonistic entity as physically close to the deictic centre. Temporal proximization involves the forced construal of 'now' as defined by the current state of affairs through temporal orientation shifts. Past-to-present orientation involves the construal of past events and actions performed by ODC in order to account for the current phenomena, while future-to-present orientation involves the construal of future ODC actions stemming from the present state of affairs. Epistemic proximization involves a shift alongside the epistemic axis representing a scale of values ranging from absolute commitment to complete detachment of the speaker from the likelihood that some state of affairs becomes actualized (Nuyts 2001), metaphorically represented as 'degrees of distance' (Fleischman 1989). Taking such epistemic stance deictically involves the positioning of the speaker with respect to her/his inferential knowledge and the nature of premises from which such inference is drawn. Epistemic proximization allows speakers to set up an intersubjective space of shared values by passing their epistemic judgement, thus attaining public support (Hart 2014b: 181). In order to do so, the speaker frequently resorts to evidentiality strategies marking 'the information source' (Aikhenvald 2004) which may serve as a subtle base for the inference that forms the conceptualizer's epistemic stance. Linguistic literature (Aikhenvald 2004: 5; Chung \& Timberlake 1985: 244) is quite adamant in demarcating the categories of evidentiality and epistemic modality inasmuch as it claims that the markers of the source of knowledge do not mark the speaker's attitude towards the reliability of that information, and this is the view that we assume here. However, we do not exclude the view that certain linguistic expressions marking the source of knowledge may exhibit epistemic extensions - when they do mark reliability, possibility and probability, depending on several criteria, as reported by Aikhenvald (cf. 2004: 6).

In his original model, Paul Chilton included spatial, temporal and modal axis (2004). Piotr Cap developed the said DS model by proposing axiological instead of the modal plane (2013), while the final elaboration was provided by Hart (2014b) who included spatial, temporal, and evaluative (epistemic/axiological) axis. DST 
theory was later referred to as Deictic Space Theory by Chilton (2014: 29), and the spatial plane was replaced by a deictic axis that mentally positions discourse referents whose distance from the deictic centre is not necessarily physical (for instance, the use of deictic demonstratives this and that positions the referents at a relative distance from the reference point, and does not confine them to a spatial dimension).

As opposed to DST, Proximization relies on the level of discourse, not sentential level of analysis, and it accounts for dynamic discourse space construal that involves constant shifts in viewpoint, thus different degrees of salience of the three axes. Furthermore, it raises the question of legitimization goals that such (interventionist) discourse aims to accomplish (Cap 2013: 22).

\section{Research and methodology}

The overall aims of the present research were:

1) to identify the linguistic instantiations of pragmatic positioning strategies in the sampled public briefings in the contemporary Anglo-American political discourse;

2) to present the STE model of spatial, temporal and epistemic proximization strategy and the underlying construal operations of such discourse representation;

3) to reveal the patterns of proximization strategy used for legitimization purposes in the Anglo-American political discourse.

The overall goal was to present how the discursive choice of different language constructions yields ideologically fused mental representations, eventually leading to legitimization of the undertaken actions. For the purpose of the present analysis, two smaller corpora were compiled from the samples of the political statements from Anglo-American quality press (The Guardian, The New York Times) and transcripts of public briefings. The samples cover the period of six months (March-August, 2020) and the same topics (the spread of the Coronavirus, economic measures, preventive actions - lockdown, curfew, the state of national healthcare systems). The overall number of samples in 
both corpora (US and UK) is 85, the average sample length being 2,000 words. The approximate overall size of the corpus is 170,000 words. The frequency of proximization markers occurrence has been normalized to 100 words. Altogether, there were 27 speakers whose statements entered the corpora.

\section{Findings}

For the purpose of the present analysis, the three positioning strategies are presented separately, even though in the ongoing discourse all three strategies are utilized simultaneously, with constant conceptual shifts in their salience.

\subsection{Spatial proximization}

Spatial proximization involves a conceptual representation (script) of an interaction between an ANTAGONIST and a PROTAGONIST. The antagonistic entity (ODC), as the embodiment of negative values, is being construed as encroaching upon the protagonist's spatial ground, and their physical impact may be negatively consequential to the protagonist (IDC). The impact is always construed as immediate and destructive, unless some preventive action is taken by the IDC. Distinction between the centre and the periphery primarily involves geographical and geopolitical distance, but it may also involve ideological one (Cap 2013: 74). Speakers frequently resort to the evocation of a similar threat in the past and its disastrous consequences so as to emphasize the imminence of the current threat. The physical distance is narrowed through the use of a combination of lexical items which serve together as a prompt for proximization script.

Within the Coronavirus interventionist discourse, public support is best attained through the use of spatial proximization that allows immediate approval of the preventive measures taken by the IDC. By a way of example, let us consider the following extracts from the UK and US public briefings: 
(1) You've put up with all the hardships of that program of social distancing because you understand that as things stand - and it is the experience that every other country has shown - it's the only way to defeat the [coronavirus, the most vicious threat ANTAGONIST] that [this country PROTAGONIST] [has faced COUNTER FORCE] in my lifetime. And though the death toll has been tragic, and the [suffering RESULT] immense, and though [we PROTAGONIST] grieve for all those we have lost, it is a fact that by adopting those measures [we PROTAGONIST] [prevented COUNTER FORCE] this country from [being engulfed by FORCE] what could've been a [catastrophe RESULT] in which the reasonable worst-case scenario was half a million fatalities.

This clear-cut case of spatial proximization involves the forced construal of the PROTAGONIST as 'this country' and 'we', thus including the addressees in such conceptualization and invoking an intersubjective spatial situatedness. The antagonistic entity is represented as 'the coronavirus', 'the most vicious threat', and is located at a near point on the s-axis. Furthermore, another spatial component is evoked by making the analogy with other countries, thus increasing the imminence of the current threat. The dynamicity of the proximization strategy is captured by the ACTION and FORCE image schematic representation of the point of contact and resulting consequences for the deictic centre. The COUNTER FORCE schema involves reciprocal exchange of energies, thus neutralizing the progressive force of the antagonist. ODC is metaphorically framed as a THREAT whose actions result in suffering and catastrophe. Since the counter actions managed to 'save' the country from the possible worst-case scenario of a catastrophe, the counterfactual event is positioned temporally, spatially and epistemically the furthest from the deictic centre.

(2) This is the most aggressive and comprehensive effort to [confront ACTION] [a foreign virus ANTAGONIST ] in modern history. I am confident that by counting and continuing to take these tough measures, [we PROTAGONIST ] will significantly reduce [the threat ANTAGONIST] [to DIRECTION] [our citizens 
PATIENT] and we will ultimately and expeditiously [defeat ACTION] [this virus ANTAGONIST].

In the US political discourse, the point of contact between ODC and IDC is construed by the RECIPROCAL ACTION schema that involves a bidirectional encounter instantiated by the expression 'confront'. Furthermore, that schema is elaborated metaphorically to produce the WAR metaphor, mentally representing the ODC as an 'enemy' that must be 'defeated'. Similarly, the IDC is construed by the intersubjective 'we' that establishes the viewpoint and deictic centre. The indefinite article positions ODC further from the deictic centre, and vice versa; the use of the definite article as a marker of proximity assigns the proximal value to the antagonistic entity on the spatial axis.

(3) [The coronavirus ANTAGONIST] is [the biggest threat ANTAGONIST] [this country PROTAGONIST] [has faced COUNTER FORCE] for decades. And this country is not alone. All over the world we are seeing the devastating impact of [this invisible killer ANTAGONIST]... Without a huge national effort to halt the growth of [this virus ANTAGONIST], there will come a moment when no health service in the world could possibly cope.

The figure that follows presents not only the spatial axis (as marked in the excerpts), but aims at modelling the dynamicity of the overall proximization process of mental representation. When construal is evoked progressively as discourse unfolds we talk about narrative proximization (Hart 2014b: 170). The small letters mark the key items that trigger the construal operations. Different letters capture the dynamic process of the shift in salience of the three axes ( $\mathrm{S}$ - spatial; $\mathrm{E}_{\mathrm{a}}$ - epistemic/axiological; $\mathrm{t}$-/ $\mathrm{t}+$ - temporal past and future). The counter force schema is presented by two opposing force vectors. The intersecting point of all axes is the deictic centre, i.e. the point of view of the proximizing events. 


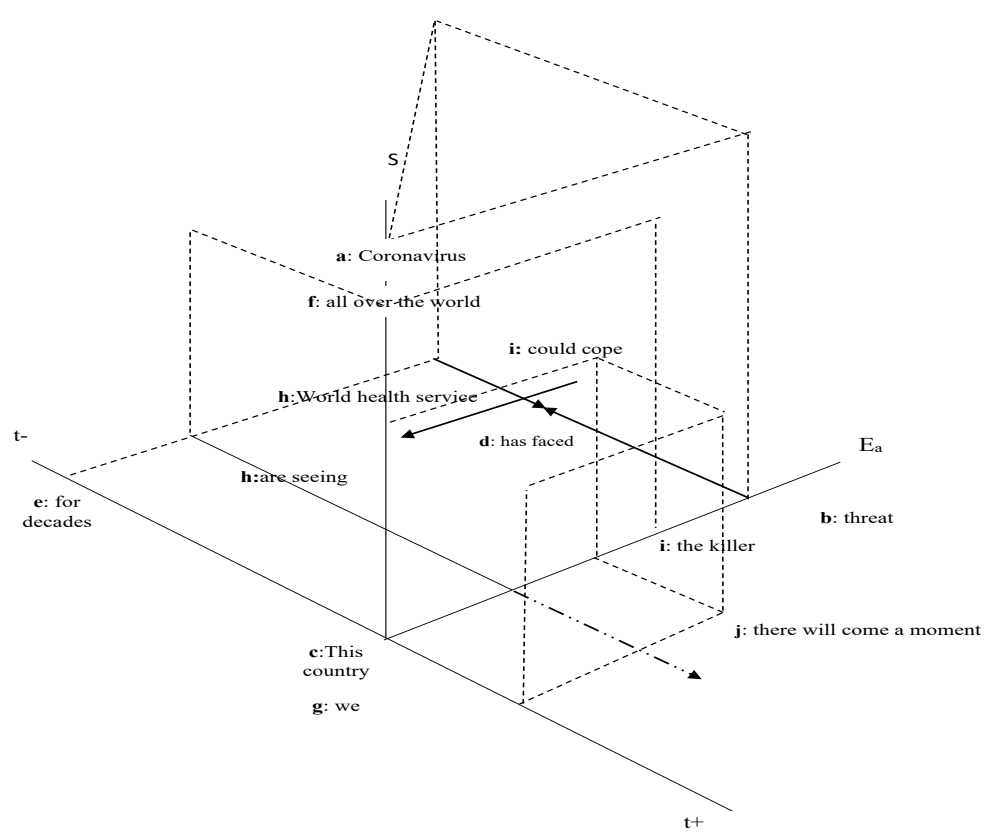

Figure 2. Narrative proximization

We may now produce the spatial proximization framework as identified by the current analysis, on the basis of the previous research conducted by Cap (2013) and Hart (2014a). The identified spatial viewpoint is metaphorically extended to temporal and epistemic proximization. The key linguistic items had to make the frequency threshold of 1 occurrence per 100 words in order to be included in the framework. The square brackets contain individual conceptual items, and a combination of those that are 'conceptually synonymous' (Cap 2013), i.e. that are elaborated by the same conceptual frame, thus instead of counting them individually, we took a combined normalized count of those instances. 
Table 1. Spatial proximization framework and corresponding construal operations in the Coronavirus interventionist discourse

\begin{tabular}{|c|c|c|}
\hline CATEGORY & KEY ITEM & CONSTRUAL OPERATION \\
\hline $\begin{array}{c}\text { NPs } \\
\text { construed as } \\
\text { elements of } \\
\text { the deictic } \\
\text { centre (IDCs) }\end{array}$ & $\begin{array}{l}\text { ['UK', 'the United } \\
\text { Kingdom', 'the } \\
\text { British'], ['US', 'the } \\
\text { United States', } \\
\text { 'America', 'the } \\
\text { American people'], } \\
\text { ['our nation', } \\
\text { 'the county', 'this } \\
\text { country'], [people, } \\
\text { population]'[we, us]' }\end{array}$ & $\begin{array}{l}\text { Schematization } \\
\text { (Protagonist) } \\
\text { (Patient) } \\
\text { (Landmark) } \\
\text { Categorization }\end{array}$ \\
\hline $\begin{array}{c}\text { NPs } \\
\text { construed as } \\
\text { peripheral } \\
\text { elements of } \\
\text { the DS (ODCs) }\end{array}$ & $\begin{array}{c}\text { ['Coronavirus', } \\
\text { 'CoVID 19', 'the virus', } \\
\text { 'China virus', 'the } \\
\text { disease'], ['it'] }\end{array}$ & $\begin{array}{l}\text { Schematization } \\
\text { (Antagonist) } \\
\text { (Agent) } \\
\text { (Trajector) } \\
\text { Categorization }\end{array}$ \\
\hline $\begin{array}{c}\text { NPs } \\
\text { construed as } \\
\text { antagonistic } \\
\text { nature of ODC }\end{array}$ & $\begin{array}{c}\text { ['threat'], ['enemy'], } \\
\text { ['danger'], ['global } \\
\text { problem'] }\end{array}$ & $\begin{array}{c}\text { Schematization } \\
\text { Categorization } \\
\text { Metaphor }\end{array}$ \\
\hline $\begin{array}{c}\text { NPs } \\
\text { construed as } \\
\text { the impact of } \\
\text { the ODC Upon } \\
\text { IDC }\end{array}$ & $\begin{array}{l}\text { ['assault'], ['entry'] } \\
\text { The assault of the } \\
\text { virus on our nation; } \\
\text { we've talked with the } \\
\text { representatives of } \\
\text { Canada and Mexico to } \\
\text { halt the entry of the } \\
\text { Chinese virus }\end{array}$ & $\begin{array}{l}\text { Schematization } \\
\text { Force Dynamics } \\
\text { Categorization } \\
\text { Metaphor }\end{array}$ \\
\hline $\begin{array}{c}\text { NPs } \\
\text { construed as } \\
\text { effects of ODC } \\
\text { impact }\end{array}$ & $\begin{array}{c}\text { ['catastrophe'], } \\
\text { ['tragedy'] } \\
\text { The tragedy of the } \\
\text { new coronavirus } \\
\text { spikes }\end{array}$ & $\begin{array}{c}\text { Schematization } \\
\text { Categorization } \\
\text { Metaphor }\end{array}$ \\
\hline
\end{tabular}


SPATIAL, TEMPORAL AND EPISTEMIC PROXIMIZATION...

\begin{tabular}{|c|c|c|c|}
\hline CATEGORY & KEY ITEM & $\begin{array}{l}\text { CONSTRUAL } \\
\text { OPERATIONS }\end{array}$ & $\begin{array}{c}\text { SPATIAL } \\
\text { VIEWPOINT }\end{array}$ \\
\hline \multirow{2}{*}{$\begin{array}{l}\text { VPs of action } \\
\text { construed } \\
\text { as markers } \\
\text { of contact } \\
\text { between ODC } \\
\text { and IDC }\end{array}$} & $\begin{array}{c}\text { ['clash'] } \\
\text { UK-China virus will } \\
\text { clash and that could } \\
\text { be detrimental to our } \\
\text { wellbeing }\end{array}$ & $\begin{array}{c}\text { Schematization } \\
\text { Metaphor } \\
\text { Point of View }\end{array}$ & \\
\hline & $\begin{array}{c}\text { ['fighting'], } \\
\text { ['combat'], ['has } \\
\text { faced'] } \\
\text { We have a wartime } \\
\text { president fighting an } \\
\text { invisible enemy }\end{array}$ & $\begin{array}{c}\text { Schematization } \\
\text { Metaphor } \\
\text { Point of View }\end{array}$ & \\
\hline $\begin{array}{l}\text { VPs of force } \\
\text { construed as } \\
\text { markers of } \\
\text { force exertion } \\
\text { by ODC upon } \\
\text { the IDC }\end{array}$ & $\begin{array}{l}\text { ['engulfed by'] } \\
\text { We prevented this } \\
\text { country from being } \\
\text { engulfed by what } \\
\text { could have been a } \\
\text { catastrophe }\end{array}$ & $\begin{array}{l}\text { Schematization } \\
\text { (Motion }+ \\
\text { Force Dynamics) } \\
\text { Point of View }\end{array}$ & \\
\hline \multirow[t]{2}{*}{$\begin{array}{c}\text { VPs of } \\
\text { motion and } \\
\text { directionality } \\
\text { construed as } \\
\text { markers of } \\
\text { movement of } \\
\text { ODC towards } \\
\text { the IDC }\end{array}$} & $\begin{array}{l}\text { ['will come', 'is } \\
\text { coming'], ['will come } \\
\text { back'], } \\
\text { It's going to be the } \\
\text { winter where we're } \\
\text { really going to have } \\
\text { to be on it because } \\
\text { that's when you're } \\
\text { going to get flu, } \\
\text { general pubic health } \\
\text { problems and there's } \\
\text { a risk that the virus } \\
\text { will come back again } \\
\text { anyway. }\end{array}$ & $\begin{array}{l}\text { Schematization } \\
\text { Metaphor } \\
\text { Point of View } \\
\text { Deixis }\end{array}$ & \\
\hline & $\begin{array}{l}\text { ['will surge'] } \\
\text { The Coronavirus will } \\
\text { surge again and we } \\
\text { must be ready. }\end{array}$ & $\begin{array}{c}\text { Schematization } \\
\text { Metaphor } \\
\text { Point of View }\end{array}$ & \\
\hline
\end{tabular}




\subsection{Temporal proximization}

Temporal proximization involves the construal of the conceptualizers' 'now' as the reference point on the time axis. The 'now' is construed through the analogy with the known events of the past and the anticipated events of the future inferred from the current state of affairs. Temporal strategy rarely operates solely; it is utilized so as to intensify other proximization strategies. This is evident in the English grammatical system where motion verbs may be marked for tense and aspect (e.g. the present progressive). In phraseological proximization (Hart 2014b), the temporal strategy is realized through tense and aspect, temporal indexicals (now, then, etc.), adjectives, motion verbs, adverbs indicating speed of motion, and prepositional phrases. Temporal proximization may also be construed analogically when salient events of the past are brought closer to the temporal 'now' for the purpose of making an analogy (Cap 2013). In temporal proximization there is a compression of the time axis so that time appears 'contracted' (Cap 2013: 85; Hart 2014b: 173) so as to allow for two possible temporal shifts: past-to-present and future-to-present. For the purpose of the past-orientation strategy, the speaker utilizes grammatical and lexical forms that construe the past event as still ongoing. In future-orientation (usually construed phraseologically) the event is construed as imminent, thus requiring immediate action.

(4) Coronavirus has come to stay.

(5) The second wave of the coronavirus is coming.

(6) Coronavirus is the biggest threat this country has faced for decades.

(7) We are now facing the most dangerous threat of the XXI century.

(8) Each and every one of us is now obliged to join together to halt the spread of this disease [...], and I know that, as they have so many times in the past, the people of this country will rise to that challenge and we will come through it stronger than ever. 


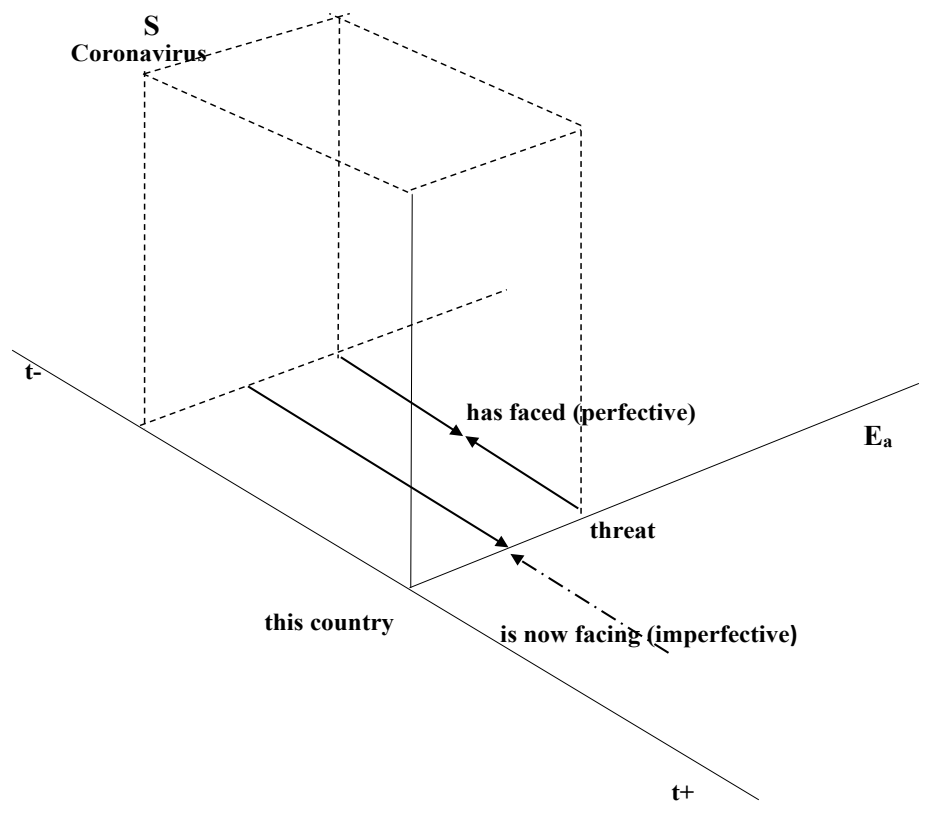

Figure 3. Perfective and imperfective aspect of temporal proximization markers

In examples (3) and (4), temporal proximization is indexed by the present tense, but also by perfective and imperfective aspect of the motion verb. The present tense locates the temporal viewpoint at the conceptualizer's temporal ground. The perfective aspect marks the motion verb as having an end-point, and that end-point is the temporal deictic centre. On the other hand, the imperfective aspect construes the motion as still ongoing, and it might continue some time in the future (Hart 2014b: 177). The invocation of the past in the analogical realization of past-oriented proximization (6) causes the present threat to be construed as more proximal. Due to time compression, the present counter actions are construed based on the inferences from the past premises when a similar situation was ongoing. Based on the inferred premises from the past and those from the present, the speaker, with a degree of certainty, 
construes the future state of affairs that depend on the present activity, which ultimately helps him legitimize preventive actions. The figures that follow were adapted from Hart's models (2014a) and developed so as to suit the present findings.

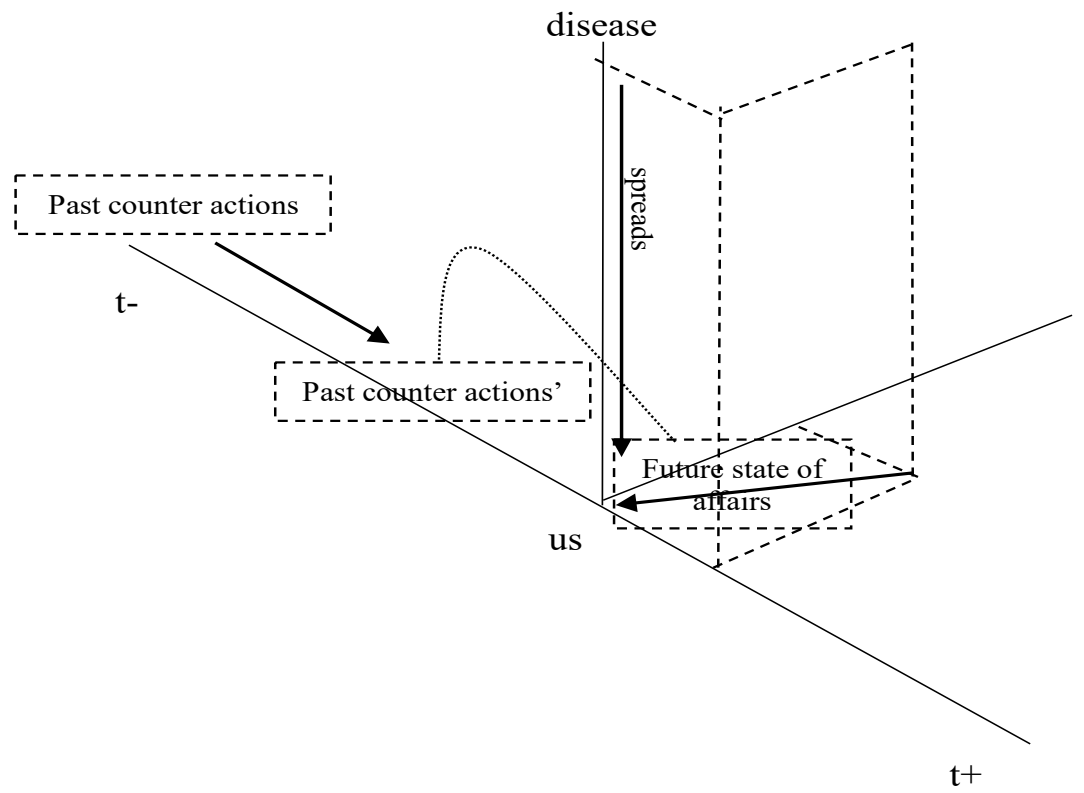

Figure 4. Past and future orientation in temporal proximization

\subsection{Epistemic proximization}

The construal of epistemic evaluation involves metaphorical extension of the space CENTRE-PERIPHERY schema, spatial viewpoint and spatial situatedness. The epistemic axis represents the irealis-realis scale of values that a proximizing entity assumes until it becomes a part of a conceptualizer's epistemic ground that serves as the viewpoint and deictic centre. The passing of the epistemic judgement presupposes the existence of some 
previously construed world in which the expressed proposition applies (Lyons 1977). Temporal representation of 'now' also involves evaluating the present state of affairs as factual with corresponding t $0 / \mathrm{e} 0$ value, indicating the close connection of the epistemic and temporal proximization. Epistemic proximization frequently operates alongside future-oriented temporal strategy to yield legitimization effect. The epistemically remote world is construed as counterfactual and placed at the remote ends of t/e scales. As anticipated events of the future can never be truly known (Langacker 2009; Nuyts 2001; Coates 1983; Palmer 1986), they are construed as nonfactual (assuming medial position on the e-axis). High certainty implies low distance, thus such evaluation is positioned the closest to the deictic centre.

(9) [We PROTAGONIST ] think EPISTEMIC that [this virus ANTAGONIST] is likely to be EPISTEMIC the one that [comes back ACTION] year on year TEMPORAL... and [communities PROTAGONIST] will become immune TEMPORAL-EPISTEMIC to it.

The use of mental state predicates (Nuyts 2001) may involve the underlying evidential basis of such epistemic stance taking. As speaker's evaluation depends on the available premises upon which the inference is drawn, the premises may be evidential in nature (Trbojević Milošević 2018: 134). Inferential evidentials (information obtained through reasoning) (Aikhenvald 2004; Papafragou et al. 2007) are inextricably related to epistemic judgement (Nuyts 2001), when the speaker expresses his and his team's (implicitly marked by the intersubjective 'we') epistemic qualification based on the information inferred from circumstantial evidence. Modal expression BE LIKELY TO positions the proximizing entity on the mid-point between possibility and certainty, and the modal will indicates a high degree of speaker's commitment, thus it is positioned closer to the deictic centre. Marked both for futurity and epistemicity, the modal auxiliary will illustrates the abovementioned temporal and epistemic conceptual relation. 


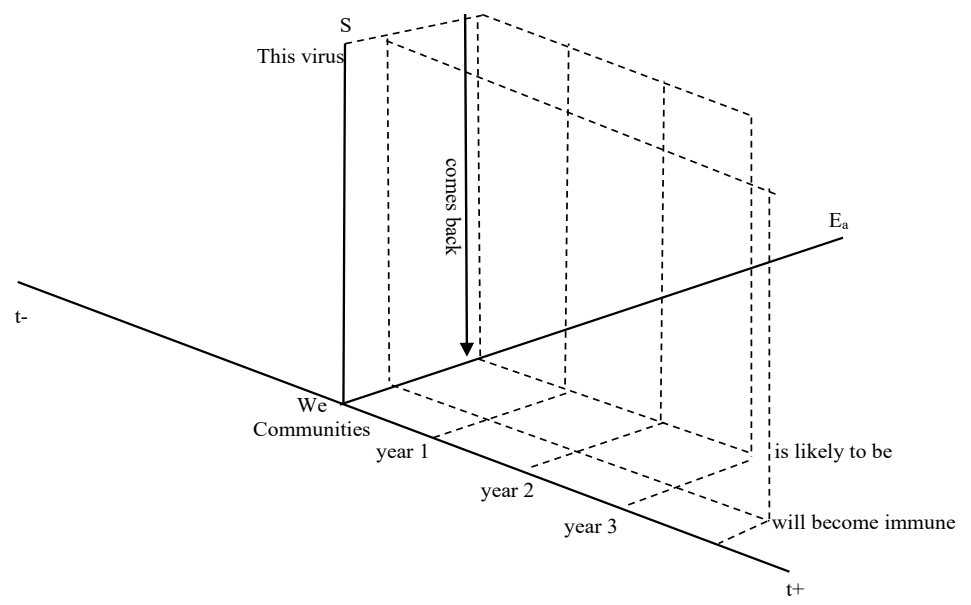

Figure 5. Epistemic proximization

(10) There's a possibility that EPISTEMIC [the assault ACTION] of [the virus ANTAGONIST] [on our nation PATIENT] next winter TEMPORAL will actually be even more difficult TEMPORALEPISTEMIC than the one [we PROTAGNOST] just TEMPORAL [went through COUNTER ACTION] ${ }^{3}$.

(11) [This virus ANTAGONIST] is going to keep EPISTEMIC [finding ACTION] [people PROTAGONIST]. It's going to keep EPISTEMIC [spreading through ACTION] [the population PROTAGONIST].

(12) Every day TEMPORAL I know EPISTEMIC that [this virus ANTAGONIST] [brings ACTION] [new sadness and mourning RESULT] [to households across the land RECIPIENT].

The use of inferential BE GOING TO (Frawley 2008: 115) in (9) implies high probability judgement based on inferential evidence. In its degree of likelihood, BE GOING TO marks higher qualificational

3 Counter action metaphorically conceptualized as movement through space, based on the EVENT STRUCTURE metaphor (Lakoff 1993). 
judgement than will. The factual mental predicate know in (10) indicates the highest degree of certainty in the truth value of the proposition (Lyons 1977: 794) and it positions the evaluated state of affairs the closest to the deictic centre. Epistemic proximization strategy serves the purpose of maintaining credibility by setting up an intersubjective space in which the anticipated state of affairs, i.e. the point of contact between the Coronavirus and the deictic centre is established fact. Therefore, the forced construal involves the evocation of a shared spatial, temporal and epistemic viewpoint of the event within the DS and the evocation of a proximizing entity as getting closer to the deictic centre. In this way, speakers are able to neutralize the addressees' ability to filter out false information (Sperber et al. 2010), thereby attaining public support. Every instance of legitimization necessarily presupposes implicit acts of coercion (speech acts, setting the topic of conversation, making assumption about reality that adressees are obliged to accept, commands, laws, etc.) and fear appeals (Chilton 2004; Cap 2013). In the case of the Coronavirus interventionist discourse, fear appeals occur as a speaker's reaction to the material threat and its devastating impact ('tragedy', 'catastrophe', 'death', 'casualties', etc.) upon both the speaker and the addressees. In the midst of such need of 'urgent reaction', the speaker opts for the justification of the preventive measures against the external threat that could possibly grow if left unattended. The duality of 'us' and 'it', 'home' and 'threat', 'life' and 'death', 'peace' and 'war' is what ultimately leads to the immediate legitimization of counter actions already taken, or yet to be taken, by the ruling party.

\section{Concluding remarks}

The critical analysis of lexico-grammatical choices in the Anglo-American political discourse pertaining to the Coronavirus pandemic confirmed the pervasiveness of the proximization strategy for the purpose of threat representation. Utilization of the strategy in question is based on the basic construal operations schematization, categorization, metaphor, point of view and deixis, 
that allow the establishment of spatial, and its metaphorically extended temporal and epistemic viewpoints. Spatial viewpoint involves mental representation of 'home' and 'threat', and is triggered primarily by noun phrases that mark the entity inside and entities outside the deictic centre, noun phrases that realize metaphorical representation of the ODCs negative nature through the WAR metaphor, and the verbal exponents of motion, action and force of the threat in question. This representation is further supported by the temporal proximization exponents - primarily tense and aspect of VPs, temporal adverbials and PrepPs, as well as epistemicity markers - mental state predicates, modals/semimodals, adverbials and modal adjectives. The invocation of the past state of affairs to construe the present threat is shown to be the case of past-to-present temporal orientation, which puts the threat closer to the temporal deictic centre. The use of mental state predicates has confirmed earlier analyses (Nuyts 2001; Aikhenvald 2004; Trbojević Milošević 2018) of their underlying (inferrential) evidential basis. The analysis has shown the dynamic character of the forced construal by presenting the STE model of narrative proximization that illustrates the shift in salience of the three axes of discourse space. Threat representation calls for an immediate legitimization of the past/present/future actions, thus is frequently utilized in the Coronavirus interventionist discourse.

As the present paper was designed to be a small-scale study, the findings regarding threat representation should be further supported by future analyses pertaining to construal operations and their pragmatic effects in the political discourse whose aim does not necessarily involve the goal of legitimization, and whose topics would exceed the topic of the current pandemic. Furthermore, bigger corpora should be compiled to account for other phenomena - additional metaphors and other construal operations involved in threat representation. Finally, a cross-linguistic analysis could be carried out for the purpose of establishing a degree of typological similarities and differences in the utilization of the proximization strategy. 


\section{REFERENCES}

Aikhenvald 2004: A. Aikhenvald, Evidentiality. Oxford: Oxford University Press.

Cap 2008: P. Cap, Towards the proximization model of the analysis of legitimization in political discourse. Journal of Pragmatics, 40, 17-41.

Cap 2013: P. Cap, Proximization: The pragmatics of symbolic distance crossing. Amsterdam: John Benjamins.

Coates 1983: J. Coates, The semantics of the modal auxiliaries. London: Croom Helm.

Chilton 2004: P. Chilton, Analyzing political discourse: Theory and practice. London/New York: Routledge.

Chilton \& Schäffner 2002: P. Chilton, C. Schäffner, Politics as text and talk: Analytic approaches to political discourse. Amsterdam: John Benjamins.

Chung \& Timberlake 1985: S. Chung, A. Timberlake, Tense, aspect and mood. In: T. Shopen (ed.), Language typology and syntactic description, vol. III: Grammatical categories and the lexicon, Cambridge: Cambridge University Press, 202-258.

Croft \& Cruse 2004: W. Croft, D. A. Cruse, Cognitive linguistics. Cambridge: Cambridge University Press.

Fillmore 1997[1971]: C. Fillmore, Lectures on deixis. Stanford: Center for the Study of Language and Information.

Fleischman 1989: S. Fleischman, Temporal distance: A basic linguistic metaphor. Studies in Language: International Journal sponsored by the Foundation "Foundations of Language", 13(1), 1-50.

Frawley 2008: W. Frawley, The expression of modality. Berlin/New York: Mouton De Gruyter.

Halliday 1985: M. A. K. Halliday, An introduction to functional grammar. London: Edward Arnold.

Hart \& Cap 2014: C. Hart, P. Cap, Contemporary discourse studies. London/ New York: Bloomsbury Publishing.

Hart 2014a: C. Hart, Construal operations in online press reports of political protests. In: P. Cap, C. Hart (eds.), Contemporary critical discourse studies, London/New York: Bloomsbury Publishing, 167-188.

Hart 2014b: C. Hart, Discourse, grammar and ideology: Functional and cognitive perspectives. London/New York: Bloomsbury Academic.

Lakoff 1993: G. Lakoff, Contemporary theory of metaphor. In: A. Ortony (ed.), Metaphor and thought, Cambridge: Cambridge University Press, 202-251. 
Langacker 2007: R. Langacker, Cognitive grammar. In: D. Geeraerts, H. Cuyckens (eds.), The Oxford handbook of cognitive linguistics, Oxford: Oxford University Press, 421-462.

Langacker 2009: R. Langacker, Investigations in cognitive grammar. Berlin: Mouton de Gruyter.

Langacker 1990: R. Langacker, Concept, image, and symbol: The cognitive basis of grammar. Berlin: Mouton de Gruyter.

Langacker 1987: R. Langacker, Foundations of cognitive grammar: Theoretical prerequisites. Stanford, CA: Stanford University Press.

Lyons 1977: J. Lyons, Semantics. Cambridge: Cambridge University Press.

Nuyts 2001: J. Nuyts, Epistemic modality, language and Conceptualization. Amsterdam/Philadelphia: John Benjamins.

Palmer 1986: F. R. Palmer, Mood and modality. Cambridge: Cambridge University Press.

Papafragou et al. 2007: A. Papafragou, P. Lee, Y. Choi, C. Han, Evidentiality in language and cognition. Cognition, 103(2), 253-299.

Portner 2009: P. Portner, Modality. Oxford: Oxford University Press.

Sperber et al. 2010: D. Sperber, F. Clément, C. Heintz, O. Mascaro, H. Mercier, G. Origgi, D. Wilson, Epistemic vigilance. Mind \& Language, 24(4), 359-393.

Talmy 1996: L. Talmy, Fictive motion in language and "ception". In: P. Bloom, M. Peterson, L. Nadel, M. F. Garrett (eds.), Language and space, Cambridge, MA: MIT Press, 211-276.

Talmy 1988: L. Talmy, Force dynamics in language and cognition. Cognitive Science, 12, 49-100.

Talmy 2000: L. Talmy, Toward a cognitive semantics: Concept structuring systems. Cambridge, MA: MIT Press.

Trbojević Milošević 2018: I. Trbojević Milošević, Corpus evidence for evidentials in English and Serbian political interviews. Belgrade English Language and Literature Studies, 10, 131-156.

van Dijk 2009: T. van Dijk, Critical discourse studies: A sociocognitive approach. In: R. Wodak, M. Meyer (eds.), Methods for critical discourse analysis, London: Sage, 62-86.

Verhagen 2007: A. Verhagen, Construal and perspectivization. In: D. Geeraerts, H. Cuyckens (eds.), The Oxford handbook of cognitive linguistics, Oxford: Oxford University Press, 48-81.

Wodak 2009: R. Wodak, The discourse of politics in action: Politics as usual. London: Palgrave Macmillan. 


\section{Lena Ninković}

\section{PROSTORNA, TEMPORALNA I EPISTEMIČKA PROKSIMIZACIJA KAO DINAMIČKE STRATEGIJE IZOBRAŽENJA DOGAĐAJA}

\section{Rezime}

Izobraženje događaja, entiteta ili odnosa zavisi od jezičkih formi koje aktiviraju različite pojmovne predstave. Izbor leksičkogramatičke jedinice koja služi kao „podsticaj” za konceptualizaciju evocira niz pojmovnih operacija koje strukturiraju naše razumevanje sveta. Diskurzivne strategije koje takve operacije ostvaruju proizvode perlokucione efekte kod slušalaca putem simboličkog izobraženja događaja, što nužno podrazumeva deiktičku tačku gledišta, tj. ukotvljenu perspektivu iz koje „vidimo” događaj. Takvo pragmatičko pozicioniranje može podrazumevati i upotrebu strategije proksimizacije u kojoj govornik, radi postizanja javne podrške evocira pojam antagonističkog entiteta koji upada na konceptualizatorovu teritoriju prostornom, vremenskom ili epistemičkom ravni diskursnog prostora. Ovaj rad ispituje diskurzivno izobraženje korona virusa kao entiteta koji se približava deiktičkom centru u angloameričkom političkom diskursu sa ciljem rasvetljavanja pragmatičnih efekata i osnovnih operacija izobraženja kojima se postižu mentalne predstave spoljne opasnosti kod slušalaca. Podaci za istraživanje se sastoje od političkih izjava predstavnika vladajuće stranke u Velikoj Britaniji i SAD-u na službenim informativnim sastancima COVID 19. Istraživanje je pokazalo da se u oba korpusa javljaju leksički i gramatički oblici koji realizuju strategiju intersubjektivnog prostornog, vremenskog i epistemičkog pozicioniranja radi postizanja zajedničke tačke gledišta, na taj način legitimizujući politike i akcije sprovedene tokom pandemije.

Ključne reči: proksimizacija, politički diskurs, legitimizacija, kognitivna pragmatika, tačka gledišta. 